\section{RBP passa a publicar os artigos no prelo na SciELO e no MEDLINE}

A produção do conhecimento científico e o fluxo das informações vêm adquirindo mais velocidade com a disponibilização em meios eletrônicos. Os pesquisadores necessitam comunicar o quanto antes os seus achados para que outros pesquisadores possam se beneficiar dos resultados e citar as publicações. As revistas de maior qualidade não conseguem publicar os artigos novos que aprova sem um período de espera considerável, o que leva a um atraso na divulgação do conhecimento.

Para acelerar este processo, vários periódicos científicos têm se utilizado de publicações eletrônicas. Desta forma, as revistas têm disponibilizado on-line os artigos aceitos para publicação antes da impressão em papel.

Tendo em vista este panorama, a Revista Brasileira de Psiquiatria (RBP) tomou iniciativa e solicitou à SciELO (Scientific Eletronic Library Online) um mecanismo que possibilitasse a divulgação de artigos científicos na íntegra antes da sua publicação em papel. O desafio da SciELO foi disponibilizar o artigo antes da sua publicação sem perder a informação associada à localização e às medidas de uso do artigo científico, tais como links, número de acessos, citações e fator de impacto.

Desde julho de 2006, a SciELO disponibiliza on-line os artigos aceitos (in press) da RBP antes de sua publicação no papel. E estes artigos já estão indexados no MEDLINE e disponíveis no site do PubMed com a designação 'ahead of print'. Através do link com a SciElo é possível acessar o artigo na íntegra e citá-los.

A parceria com a SciELO tem sido fundamental para o salto qualitativo alcançado pela RBP com a indexação no MEDLINE (National Library of Medicine/PUBMED) e no Science Citation Index (Journal of Citation Report, Thomson-ISI). A disponibilização de artigos que estão no prelo através do MEDLINE e da SciELO representa uma inovação importante que vai permitir uma maior eficiência na comunicação científica e tornar as revistas nacionais ainda mais atraentes para publicação das pesquisas de ponta.

\section{RBP started to publish articles inpress in SciELO and MEDLINE}

Scientific knowledge production and information flow have become faster with the advent of electronic media. Researchers need to communicate as soon as possible their findings to allow other researchers to benefit from their results and cite the publications. High-quality journals fail to publish the accepted new articles without a considerable waiting time, leading to a delay in the divulging of knowledge.

In order to accelerate this process, several scientific journals have been using electronic publications. Therefore, they have published online the articles accepted for publication before their printing.

Considering this situation, the Revista Brasileira de Psiquiatria (RBP) took the initiative and asked SciELO (Scientific Electronic Library Online) to provide a mechanism to allow the access to full scientific articles before their printing. SciELO's challenge was to publish the scientific article before its printing, without losing the information associated to its location and measurement of assessment, such as links, number of hits, citations and impact factor.

Since July 2006, SciELO started publishing on-line RBP's inpress articles before ahead publication. And these articles are already indexed to MEDLINE and are available at PubMed's site under the designation 'ahead of print'. By following the link to SciElo it is possible to access the full articles and cite them.

The partnership with SciELO has been fundamental for the qualitative leap forward reached by the RBP due to its indexing to MEDLINE (National Library of Medicine/PUBMED) and Science Citation Index (Journal of Citation Report, Thomson-ISI). The publication of in-press articles through MEDLINE and SciELO represents an important innovation, which will allow a higher efficacy in the scientific communication and make Brazilian journals even more attractive for the publication of state-of-theart researches.
Editores

Rodrigo A Bressan

Eurípides C Miguel

Hermano Tavares

Luiz Augusto Rohde

Marcos T Mercadante

Jair J Mari

ScIELO

Abel L. Paker

Diretor BIREME/OPAS/OMS
Editors

Rodrigo A Bressan

Eurípides C Miguel

Hermano Tavares

Luiz Augusto Rohde

Marcos T Mercadante

Jair J Mari

SciELO

Abel L. Paker

Diretor BIREME/OPAS/OMS 